\title{
KUALITAS PEMBERIAN SUSU ETAWA TERHADAP PENINGKATAN BERAT BADAN PADA PASIEN TB PARU DAN TB MDR
}

\author{
Herlia Sumardha Nasution $^{1 *}$, Purnama Handayani ${ }^{2}$, Rizki Noviyanti \\ Harahap $^{3}$ \\ ${ }^{1,2,3}$ Universitas Haji Sumatera Utara (Fakultas Ilmu Kesehatan/ \\ Program Studi Ilmu Kebidanan, Indonesia) \\ Email: herliasumardha5787@gmail.com, purnamaandayani@gmail.com, \\ kikiharahap91@gmail.com
}

\begin{abstract}
Pulmonary TB is an infection caused by mycobacterium tuberculosis. These bacteria infect the lungs. Patients usually experience symptoms of a prolonged cough to bloody cough, decreased appetite, weight loss. This study aims to determine the effect of giving etawa milk on weight gain in pulmonary tuberculosis patients at Tanjung Rejo Public Health Center. This study used a research design with a quasi-experimental approach and one group pre and post-test design. The population was in this study was pulmonary tuberculosis patients. until as many as 30 people. The results of patients with pulmonary tuberculosis, the majority of pre-milk etawa, the weight of $45 \mathrm{~kg}$ pulmonary tuberculosis patients were 5 people (33.5\%) and weight of $43 \mathrm{~kg}$ multi-drug resistant patients were 4 people $(26.7 \%)$. The results of patients with pulmonary tuberculosis, the majority of post milk etawa, the weight of $47 \mathrm{~kg}$ pulmonary tuberculosis patients were 7 people (46.7\%) and weight of $45 \mathrm{~kg}$ multi-drug resistant patients were 5 people (33.3\%). Pulmonary tuberculosis patients (0.049) and multi-drug resistant patients (0.047) there is an effect of giving etawa milk on weight gain in pulmonary tuberculosis and multi-drug resistant patients at the Tanjung Rejo Public Health Center, Deli Serdang Regency, 2020. The results showed that giving etawa milk can improve appetite which results in body weight. It is recommended for patients to participate in practicing the efficacy of etawa milk for the traditional treatment of pulmonary $T B$ disease.
\end{abstract}

\section{Key words: Etawa's milk, Weight, Pulmonary TB, MDR}

\section{PENDAHULUAN}

Tuberkulosis (TB) paru merupakan salah satu penyakit menular yang masih menjadi permasalahan di dunia hingga saat ini, tidak hanya di negara berkembang tetapi juga di negara maju. World Health Organization (WHO) memperkirakan sepertiga penduduk dunia telah terinfeksi oleh TB paru. Hal ini dibuktikan dengan masih banyaknya jumlah penderita TB paru yang ditemukan di masyarakat dan sejak tahun 1993, WHO menyatakan bahwa
TB paru merupakan kedaruratan global bagi kemanusiaan (WHO, 2013).

Organisasi Kesehatan Dunia memperkirakan 9 juta kasus tuberkulosis baru terjadi secara global pada tahun 2015 dan sebanyak 480.000 kasus diantaranya adalah multi drug-resistant TB (MDR-TB). Hanya seperempat dari jumlah kasus MDR tersebut (kurang lebih 123.000) terdeteksi dan dilaporkan. Sementara itu, XDR-TB dilaporkan terjadi di 105 negara pada tahun 2015. Sekitar 9,7\% pasien dengan 
MDR-TB diperkirakan memiliki XDRTB (WHO, 2013).

Jumlah kasus baru TB di Indonesia sebanyak 420.994 kasus pada tahun 2017 (data per 17 Mei 2019). Berdasarkan jenis kelamin, jumlah kasus baru TBC tahun 2017 pada laki-laki 1,4 kali lebih besar dibandingkan pada perempuan. Bahkan berdasarkan Survei Prevalensi Tuberkulosis prevalensi pada laki-laki 3 kali lebih tinggi dibandingkan pada perempuan. Begitu juga yang terjadi di negara-negara lain. Hal ini terjadi kemungkinan karena laki-laki lebih terpapar pada fakto risiko TBC misalnya merokok dan kurangnya ketidakpatuhan minum obat. Survei ini menemukan bahwa dari seluruh partisipan laki-laki yang merokok sebanyak $68,5 \%$ dan hanya $3,7 \%$ partisipan perempuan yang merokok (Departemen Kesehatan RI, 2017).

Dinas Kesehatan (Dinkes) Sumatera Utara (Sumut) angka penemuan penderita TB paru dengan BTA positif tahun 2016 sebanyak 14.227 penderita, dengan rata-rata kasus atau case detection rate (CDR) sebesar 40,09\%. Pada tahun 2017, Cross Notification Rate/CNR (kasus baru) TB Paru BTA (+) di Sumatera Utara baru mencapai 105,02/100.000 penduduk. Pencapaian per Kab/Kota, 3 (tiga) tertinggi adalah Kota Medan sebesar 3.006/100.000, Kabupaten Deli serdang sebesar
2.184/100.000 dan Simalungun sebesar 962/100.000). Sedangkan 3 (tiga) Kab/Kota terendah adalah Kabupaten Nias Barat sebesar 50/100.000, Pakpak Bharat sebesar 67/100.000 dan Gunung Sitoli sebesar 68/100.000 (Sumut, 2018).

Pemanfaatan susu kambing dalam program terapi pasien TB memperoleh hasil yang signifikan. Rata-rata setelah 1 bulan pemberian obat anti TB yang disertai dengan perubahan pola makan dan pemberian susu kambing $200 \mathrm{cc}$ perhari tingkat kesehatan penderita mengalami perubahan. Hal ini ditandai dengan nafsu makan yang membaik, batuk dan sesak nafas berkurang serta muka tidak tampak pucat lagi (Hatta, 2018).

Berdasarkan survey awal di Puskesmas Tanjung Rejo Kabupaten Deli Serdang pada tanggal 08 Oktober tahun 2018 yang menderita TB paru sebanyak 108 orang pada bulan JanuariOkober 2018 dan pada bulan Oktober sebanyak 83 orang dan sudah diberikan kepada 3 orang dari 5 pasien TB Paru di bulan November yang diberikan susu etawa cair $250 \mathrm{cc}$ perhari selama dua minggu terdapat $\mathrm{BB}$ pasien awal $45 \mathrm{~kg}$ menjadi $47 \mathrm{~kg}$, pasien kedua dengan BB $48 \mathrm{~kg}$ menjadi $50 \mathrm{~kg}$ dan pasien ketiga dengan BB $49 \mathrm{~kg}$ mejadi $50 \mathrm{~kg}$ dengan minum susu etawa terbukti nafsu makan bertambah setelah rutin minum susu 
etawa. Terlihat bahwa pasien TB paru banyak yang mengalami penurunan berat badan.

Berdasarkan data diatas maka penulis tertarik untu melakukan penelitian tentang Pengaruh pemberian susu etawa terhadap peningkatan berat badan pada pasien TB paru dan TB MDR.

\section{METODE}

Jenis penelitian ini bersifat penelitian eksperimen semu (quasi experiment) dengan desain penelitian ini menggunakan metode Pretest- Posttest Control Group Design. Lokasi penelitian di Puskesmas Tanjung Rejo Kabupaten Deli Serdang dengan. Data pasien TB paru. Dari data Prolanis Puskesmas sampel diambil secara Purposive Sampling, sampling didapatkan responden sebanyak 30 orang di wilayah kerja Puskesmas Tanjung Rejo. Pemberian susu dilakukan selama 4 minggu dan dilakukan penimbangan berat badan. Analisis data menggunakan Uji-T.

\section{HASIL DAN PEMBAHASAN}

\section{Data Demografi}

Data demografi responden di wilayah Puskesmas Tanjung Rejo Kabupaten Deli Serdang dapat dilihat pada tabel dibawah ini:

Tabel 1. Distribusi Responden Berdasarkan Karakteristik Data Demografi

\begin{tabular}{|c|c|c|c|c|c|}
\hline \multirow{2}{*}{ No } & \multirow{2}{*}{ Data Demografi } & \multicolumn{2}{|c|}{ TB Paru } & \multicolumn{2}{|c|}{ TB -MDR } \\
\hline & & $f$ & $\%$ & $f$ & $\%$ \\
\hline \multirow[t]{5}{*}{1} & Umur & & & & \\
\hline & 17-20 tahun & 1 & 6,7 & 2 & 13,3 \\
\hline & 21-35 tahun & 8 & 53,3 & 4 & 26,7 \\
\hline & $>35$ tahun & 6 & 40,0 & 9 & 60,0 \\
\hline & Jumlah & 15 & 100 & 15 & 100 \\
\hline \multirow[t]{7}{*}{2} & Pendidikan & & & & \\
\hline & Tidak sekolah & 0 & 0 & 1 & 6,7 \\
\hline & SD & 2 & 13,3 & 2 & 13,3 \\
\hline & SMP & 4 & 26,7 & 8 & 53,3 \\
\hline & SMA & 9 & 60,0 & 3 & 20,0 \\
\hline & Perguruan Tinggi & 0 & 0 & 1 & 6,7 \\
\hline & Jumlah & 15 & 100 & 15 & 100 \\
\hline \multirow[t]{6}{*}{3} & Pekerjaan & & & & \\
\hline & PNS & 1 & 6,7 & 0 & 0 \\
\hline & Bertani & 4 & 26,7 & 2 & 13,3 \\
\hline & Wiraswasta & 8 & 53,3 & 9 & 60,0 \\
\hline & IRT & 2 & 26,7 & 4 & 26,7 \\
\hline & Jumlah & 15 & 100 & 15 & 100 \\
\hline \multirow[t]{4}{*}{4} & Pendapatan & & & & \\
\hline & $>\operatorname{Rp} 2.000 .000$ & 6 & 40,0 & 4 & 26,7 \\
\hline & $<\mathrm{RP} 2.000 .000$ & 9 & 60,0 & 11 & 73,3 \\
\hline & Jumlah & 15 & 100 & 15 & 100 \\
\hline
\end{tabular}


Berdasarkan Tabel 1 Data demografi responden mayoritas pasien TB Paru usia 21-35 tahun sebanyak 8 orang (53.3\%), sedangkan pasien TB-MDR mayoritas pasien usia >35 tahun sebanyak 9 orang $(60,0 \%)$. Mayoritas pendidikan responden pasien TB Paru adalah SMA sebanyak 9 orang $(60,0 \%)$, sedangkan pasien TB-MDR mayoritas pasien SMP sebanyak 8 orang $(53,3 \%)$.
Mayoritas pekerjaan responden pasien TB Paru adalah Wiraswata sebanyak 8 orang $(53,3 \%)$, sedangkan pasien TBMDR mayoritas pasien Wiraswata sebanyak 9 orang $(60,0 \%)$. Mayoritas penghasilan responden pasien TB Paru adalah $<2.000 .000$ sebanyak 9 orang $(60,0 \%)$, sedangkan pasien TB-MDR mayoritas pasien $<2.000 .000$ sebanyak 11 orang $(73,3 \%)$.

Tabel 2. Distribusi Berat Badan Responden (Pre Test)

\begin{tabular}{|c|c|c|c|c|c|}
\hline \multirow{2}{*}{ No } & \multirow{2}{*}{ Berat Badan } & \multicolumn{2}{|c|}{ TB Paru } & \multicolumn{2}{|c|}{ TB-MDR } \\
\hline & & $f$ & $\%$ & $f$ & $\%$ \\
\hline 1 & $43 \mathrm{Kg}$ & 2 & 13,3 & 4 & 26,7 \\
\hline 2 & $44 \mathrm{Kg}$ & 1 & 6,7 & 2 & 13,3 \\
\hline 3 & $45 \mathrm{Kg}$ & 5 & 33.3 & 3 & 20,0 \\
\hline 4 & $46 \mathrm{Kg}$ & 2 & 13,3 & 2 & 13,3 \\
\hline 5 & $47 \mathrm{Kg}$ & 3 & 20,0 & 3 & 20,0 \\
\hline 6 & $48 \mathrm{Kg}$ & 2 & 13,3 & 2 & 13,3 \\
\hline & Jumlah & 15 & 100 & 15 & 100 \\
\hline
\end{tabular}

Berdasarkan Tabel 2 distribusi berat badan pada pasien TB paru mayoritas berat badan pasien $\mathrm{TB}$ paru $45 \mathrm{~kg}$ sebanyak 5 orang $(26.7 \%)$. Sedangkan pada pasien mayoritas berat badan pasien TB-MDR $43 \mathrm{~kg}$ sebanyak 4 orang $(26.7 \%)$.

Tabel 3. Distribusi Berat Badan Responden (Post Test)

\begin{tabular}{|c|c|c|c|c|c|}
\hline \multirow{2}{*}{ No } & \multirow{2}{*}{ Berat Badan } & \multicolumn{2}{|c|}{ TB Paru } & \multicolumn{2}{|c|}{ TB-MDR } \\
\hline & & $f$ & $\%$ & $f$ & $\%$ \\
\hline 1 & $45 \mathrm{Kg}$ & 2 & 13,3 & 5 & 33,3 \\
\hline 2 & $46 \mathrm{Kg}$ & 1 & 6,7 & 1 & 6,7 \\
\hline 3 & $47 \mathrm{Kg}$ & 7 & 46,7 & 4 & 26,7 \\
\hline 4 & $48 \mathrm{Kg}$ & 3 & 20,0 & 2 & 13,3 \\
\hline 5 & $49 \mathrm{Kg}$ & 1 & 6,7 & 2 & 13,3 \\
\hline 6 & $50 \mathrm{Kg}$ & 1 & 6,7 & 1 & 6,7 \\
\hline & Jumlah & 15 & 100 & 15 & 100 \\
\hline
\end{tabular}

Berdasarkan Tabel 3 distribusi berat badan pada pasien TB paru mayoritas berat badan $47 \mathrm{~kg}$ sebanyak 7 orang
(46,7\%). Sedangkan pada pasien TBMDR mayoritas berat badan pasien TBMDR $45 \mathrm{~kg}$ sebanyak 5 orang $(33,3 \%)$. 
Tabel 4. Kualitas Pemberian Susu Etawa Terhadap Peningkatan Berat Badan Pada Pasien TB Paru

\begin{tabular}{lcccc}
\hline \multicolumn{1}{c}{ Berat Badan } & Mean & Mean Rank & $\boldsymbol{p}$ & $\boldsymbol{t}$ \\
\hline Susu kambing (pre) & 35.33 & 0.067 & 0,000 & \multirow{2}{*}{0,049} \\
Susu kambing (post) & 35.45 & & & \\
\hline
\end{tabular}

Berdasarkan Tabel 4 Kualitas pemberian susu etawa terhadap peningkatan berat badan pada pasien TB paru rata - rata berat badan pasien TB Paru sebelum diberikan susu etawa 35,33 dan sesudah 35,45 dan nilai selisih antara sebelum dan sesudah 0.067 . Nilai $p$ hitung lebih kecil dan nilai $\mathrm{t}=0.049$ yang artinya ada pengaruh pemberian susu etawa terhadap peningkatan berat badan pada pasien TB-Paru.

Tabel 5. Kualitas Pemberian Susu Etawa Terhadap Peningkatan Berat Badan Pada Pasien TB-MDR

\begin{tabular}{ccccc}
\hline Berat Badan & Mean & Mean Rank & $\boldsymbol{p}$ & $\boldsymbol{t}$ \\
\hline Susu kambing (pre) & 34.26 & \multirow{2}{*}{0.055} & \multirow{2}{*}{0,000} & \multirow{2}{*}{0,047} \\
Susu kambing (post) & 34.32 & & \\
\hline
\end{tabular}

Berdasarkan Tabel 5 Kualitas pemberian susu etawa terhadap peningkatan berat badan pada pasien TB -MDR rata - rata berat badan pasien TB -MDR sebelum diberikan susu etawa 34,26 dan sesudah 34,32 dan nilai selisih

\section{Pembahasan}

Kualitas Pemberian Susu Etawa Terhadap Peningkatan Berat Badan Pada Pasien TB Paru

Upaya yang dilakukan dalam Menaikkan berat badan pasien TB paru dapat dilakukan dengan pengobatan nonkimiawi yaitu mengkonsumsi susu kambing secara teratur, disertai pengobatannya secara medis. Susu kambing mengandung fluorin tinggi dengan kadar 10-100 kali lebih tinggi antara sebelum dan sesudah 0.055 . Nilai $p$ hitung lebih kecil dan nilai $\mathrm{t}=0.047$ yang artinya ada pengaruh pemberian susu etawa terhadap peningkatan berat badan pada pasien TB-MDR.

dari susu sapi. Unsur ini merupakan antiseptik alami yang mengandung elemen pencegah tumbuhnya bakteri TBC. Fluorin akan meningkatkan daya tahan tubuh dan menekan aktivitas pertumbuhan bakteri TBC. Fluorin juga bisa memberi perlindungan jaringan pada paru-paru serta memproteksi ginjal dan hati. Kandungan lemak dalam susu kambing berfungsi sebagai zat pembakar sehingga tubuh penderita menjadi 
hangat. Dengan demikian, susu kambing ini mempunyai efek ganda yaitu untuk perlindungan, pencegahan sekaligus penyembuhan.

Susu kambing juga mengandung natrium tinggi. Dalam kasus penyakit TBC, salah satu pemicunya adalah malnutrisi. Dengan pemberian susu kambing secara rutin setiap hari, natrium yang terdapat di dalamnya berfungsi menghambat malnutrisi itu.

Kandungan Protein Susu Kambing Etawa Hampir Setara Dengan ASI Susu kambing etawa buat berat badan anda bukanlah isapan jempol semata. Kandungan protein dalam susu kambing etwa melebihi telur ayam dan hampir setara dengan ASI. Anda tentu tahu, bahwa bayi yang baru lahir dan hanya minum ASI mengalami pertumbuhan berat badan yang sangat pesat. Begitu pula dengan susu kambing etawa buat berat badan orang dewasa.

Berdasarkan hasil uji statistik deskriptif dari hasil pre-test dan posttest. Terdapat perbedaan nilai pretest dan posttest pemberian susu etawa. Serta nilai signifikan $0.000<0.05$ berarti ada pengaruh pemberian susu etawa terhadap peningkatan berat badan pasien TB paru.

Berdasarkan data demografi diketahui bahwa penghasilan responden mayoritas > Rp 2.000.000 dengan pendapatan tersebut bagi masyarakat umum dapat menjamin pembelian untuk pengobatan TB paru.

Kekayaan Nutrisi Susu kambing Buat Berat Badan Anda Bertambah Kandungan nutrisi dalam susu kambing etawa tentulah sangat banyak. Sebuah penelitian di Amerika menyebutkan bahwa susu kambing merupakan salah satu makanan dengan kandungan gizi paling lengkap yang pernah ada. Isinya meliputi Vitamin A, Vitamin C, Vitamin E, protein, lemak baik, karbohidrat, serat, lemak nabati, dan energi. Dengan kekayaan nutrisi sebegitu banyak, tidak heran kalau susu kambing bisa membuat badan kurus jadi gemuk dalam tempo sesingkat-singkatnya.

\section{Kualitas Pemberian Susu Etawa Terhadap Peningkatan Berat Badan Pada Pasien TB-MDR}

Umur merupakan faktor predisposisi terjadinya perubahan perilaku yang dikaitkan dengan kematangan fisik dan psikis dari penderita MDR-TB. Sekitar 75\% pasien TB di Indonesia adalah kelompok usia lanjut secara ekonomis, yakni pada usia 35 hingga 50 tahun (Achmadi, 2015).

Diperkirakan seorang pasien TB dewasa akan kehilangan rata-rata waktu kerjanya 3 sampai 4 bulan. Hal tersebut berakibat pada kehilangan pendapatan tahunan rumah tangganya sekitar 20$30 \%$ (WHO, 2013).

Pada usia yang pucaknya pada umur 40-90 tahun, angka ketidakteraturan 
berobat lebih tinggi disebabkan karena lupa dan kepasrahan mereka terhadap sakit yang diderita (Gani, 2015).

Akibat dari ketidakteraturan berobat ilmiah yang menjadi pemicu terjadinya MDR TB. Keteraturan minum obat adalah suatu perilaku dari seseorang yang tetap atau secara periodic melakukan aktivitasnya dengan tujuan pengobatan. Jadi perilaku penderita pada hakikatnya juga suatu aktivitas baik yang dapat diamati secara langsung ataupun tidak langsung. Perilaku keteraturan berobat seseorang pada dasarnya adalah respon seseorang atau organisme tderhadap stimulus yang berkaitan dengan sakit dan penyakit yang dideritanya, system pelayanan kesehatan dan pengobatanya (Sangadah, 2017).

Pasien MDR TB memulai pengobatan bila sudah terkonfirmasi MDR TB dengan pemeriksaan uji kepekaan M. tuberculosis. Keteraturan berobat dapat mencegah resistensi obat yang digunakan sehingga meningkatkan respon pengobatan. Keberhasilan pengobatan dapat diukur dengan konversi dahak dan biakan minimal setelah rutin menelan obat selama 2 bulan (Kementrian Kesehatan RI, 2017).

Hasil penelitian di Kota Surabaya menyatakan salah satu penyebab penderita memutuskan untuk drop out dari pengobatan TB adalah jarak ke pelayanan kesehatan yang cukup jauh sehingga akan menimbulkan terjadinya MDR-TB (Nuraidah, Prasetyowati, \& Aryanto, 2016).

\section{KESIMPULAN}

Berdasarkan hasil penelitian tentang pengaruh pemberian susu etawa terhadap pasien TB paru dapat ditarik kesimpulan sebagai berikut:

1. Berat badan pasien TB Paru sebelum diberi susu etawa mayoritas hanya 45 kilogram dan TB-MDR mayoritas 43 Kilogram di Puskesmas Tanjung Rejo Kabupaten Deli Serdang

2. Berat badan pasien TB Paru meningkat setelah diberi susu etawa mayoritas berat badan 47 kilogram dan TB-MDR mayoritas 45 Kilogram di Puskesmas Tanjung Rejo Kabupaten Deli Serdang

3. Berdasarkan hasil uji statistik deskriptif dari hasil pre-test dan post-test. Terdapat perbedaan nilai pretest dan posttest pemberian susu etawa terhadap peningkatan berat badan pada pasien TB Paru dengan nilai $0.000<0.05$ berarti ada pengaruh pemberian susu etawa terhadap peningkatan berat badan pasien TB paru

4. Berdasarkan hasil uji statistik deskriptif dari hasil pre-test dan post-test. Terdapat perbedaan nilai 
pretest dan posttest pemberian susu etawa terhadap nilai signifikan $0.000<0.05$ berarti ada pengaruh pemberian susu etawa terhadap peningkatan berat badan pasien TB MDR.

\section{UCAPAN TERIMA KASIH}

Penelitian ini telah selesai salah satunya adalah terlibatnya berbagai pihak sebagai pendukung, untuk itu peneliti mengucapkan terimakasih kepada

1. Kepala Kemenristek BRIN yang telah memberikan kepercayaan untuk memenagkan hibah penelitian

2. Ketua LLDIKTI Wilayah I Sumatera Utara yang telah meberikan sarana untuk mewujudkan penelitian ini

3. Kepala Dinas Kesehatan Deli Serdang dan Kepala Puskesmas Tanjung Rejo yang telah memberikan izin penelitian saya

\section{DAFTAR PUSTAKA}

Achmadi, U. F. (2015). Manajemen Penyakit Berbasis Lingkungan. Jakarta: Penerbit Buku kompas.

Departemen Kesehatan. RI, (2017). Pedoman Nasional Penanggulangan Tuberkulosis Edisi 2. Jakarta: Departemen Kesehatan RI.

Gani, H. A. (2015). . Faktor-faktor yang mempengaruhi Penderita TB Paru Putus Berobat dalam Pengobatan Jangka Panjang di RS Paru Jember. Laporan Peneltian. Jember: Lembaga Penelitian Universitas Jember.
Hatta, M. (2018). Geliat Program Tuberkulosis bagi Mereka yang Tersisih. Kompas Edisi Rabu, 19 November 2018.

Kementrian Kesehatan RI. (2017). Profil Kesehatan Indonesia Tahun 2016. Jakarta: Kementrian Kesehatan RI.

Nuraidah, L.F., Prasetyowati, I., dan Aryanto, Y. (2016). Gambaran Penderita Drop Out Pengobatan Tuberculosis yang Berobat kembali di Kota Surabaya. Skripsi. Jember: Universitas Jember.

Sangadah, U. (2017). Analisis Faktor Penyebab Terputusnya Pengobatan Tuberkolosis Paru di wilayah Kerja Dinas Kesehatan Kabupaten Kebumen. Skripsi. Depok: Universitas Indonesia.

Sumut, D. P. (2018). Laporan Evaluasi Penanggulangan $T B C$ Kabupaten/Kota di Provinsi sumut. Semarang: Dinkes Provinsi Sumut.

WHO. (2013). Guidelines for The Programmatic Management DrugResistant Tuberculosis Emergency Edition. Geneve: WHO Press. 